Passive Revolution 



\section{Passive Revolution}

\section{ABSORBING THE ISLAMIC CHALLENGE TO CAPITALISM}

Cihan Tuğal 
Stanford University Press

Stanford, California

(C) 2009 by the Board of Trustees of the Leland Stanford Junior University.

All rights reserved.

No part of this book may be reproduced or transmitted in any form or by any means, electronic or mechanical, including photocopying and recording, or in any information storage or retrieval system without the prior written permission of Stanford University Press.

Printed in the United States of America on acid-free, archival-quality paper

Library of Congress Cataloging-in-Publication Data

Tuğal, Cihan.

Passive revolution : absorbing the Islamic challenge to capitalism / Cihan Tuğal.

p. $\mathrm{cm}$.

Includes bibliographical references and index.

ISBN 978-o-8047-6144-4 (cloth : alk. paper)-ISBN 978-o-8047-6145-1 (pbk. : alk. paper)

1. Islam and politics-Turkey. 2. Islamic fundamentalism-Turkey. 3. Islamic

modernism-Turkey. 4. Capitalism-Religious aspects-Islam. I. Title.

BP173.7.T82 2009

$322 \cdot 109561-\mathrm{dc} 22$

2008046633

Typeset by Westchester Book Group in 10/14 Minion 
To Deniz 
